\title{
BIOLOGICALLY ACTIVE PLANT-DERIVED SUBSTANCES WITH ANTIMICROBIAL PROPERTIES
}

\section{SUBSTANCJE BIOLOGICZNIE CZYNNE POCHODZENIA ROŚLINNEGO O WŁASNOŚCIACH PRZECIWDROBNOUSTROJOWYCH}

\author{
Małgorzata Tokarska $\operatorname{Rodak}^{1(\mathrm{~A}, \mathrm{~B}, \mathrm{D}, \mathrm{E}, \mathrm{F})}$ \\ ${ }^{1}$ Department of Public Health, Pope John Paul II State School of Higher Education in Biała Podlaska, Poland
}

Authors' contribution Wkład autorów: A. Study design/planning zaplanowanie badań B. Data collection/entry zebranie danych C. Data analysis/statistics dane - analiza i statystyki D. Data interpretation interpretacja danych E. Preparation of manuscript przygotowanie artykułu F. Literature analysis/search wyszukiwanie i analiza literatury G. Funds collection zebranie funduszy

Tables: 0

Figures: 0

References: 30

Submitted: 2021 Jan 5

Accepted: 2021 Feb 8

\section{Summary}

Modern medicine, as well as the pharmaceutical, cosmetic and food industries appreciate the value of plant raw materials for their antiseptic, analgesic, anti-inflammatory and soothing effects. Medicinal plants, often found endemically, are often treated as potential sources of new substances with antimicrobial and antifungal activity. The aim of this study was to analyze the significance of selected medicinal and spice plants in terms of their ability to inhibit the growth of microorganisms, including those pathogenic to humans. The significance of active substances contained in selected plant species with high antimicrobial potential including Aloe vera L. and Chelidonium majus L. was described. The antimicrobial activity of plant oils, including those extracted from citrus and spice plants, was also analyzed. Plants are a rich source of many substances with a broad spectrum of activity. This knowledge has often been used in folk medicine, but it was not until the development of modern research methods that the mechanisms underlying the therapeutic properties of many plant substances and their proper use could be understood. New substances present in plant materials are constantly being discovered that may be of medical interest because of their great potential to be used against microorganisms or because of their antioxidant and anti-cancer properties.

Keywords: anti-bacterial agents, antifungal agents, essential oil, Aloe, Chelidonium

\section{Streszczenie}

Współczesna medycyna, branża farmaceutyczna, kosmetyczna i spożywcza docenia wartości surowców roślinnych w zakresie działania antyseptycznego, przeciwbólowego, przeciwzapalnego i kojącego. Rośliny lecznicze, często występujące endemicznie, traktowane są niejednokrotnie jako potencjalne źródła nowych substancji o aktywności przeciwbakteryjnej i przeciwgrzybiczej. Celem pracy była analiza znaczenia wybranych roślin leczniczych i przyprawowych w zakresie ich działania hamującego na rozwój drobnoustrojów, w tym chorobotwórczych dla człowieka. Opisano znaczenie substancji czynnych zawartych wybranych gatunkach roślin o dużym potencjale przeciwdrobnoustrojowym w tym Aloe vera L. i Chelidonium majus L. Przeanalizowano także przeciwdrobnoustrojowe działanie olejków roślinnych, w tym pozyskiwanych z roślin cytrusowych i przyprawowych. Rośliny są bogatym źródłem wielu substancji o szerokim spektrum działania. Wiedzę tę niejednokrotnie wykorzystywano w medycynie ludowej, lecz dopiero rozwój współczesnych metod badawczych umożliwił poznanie mechanizmów leżących u podstaw własności leczniczych wielu substancji pochodzenia roślinnego i właściwego ich wykorzystania. Wciąż odkrywane są nowe substancje obecne w surowcach roślinnych, które mogą mieć znaczenie w medycynie ze względu na duży potencjał w niszczeniu drobnoustrojów lub ze względu na właściwości przeciwutleniające czy przeciwnowotworowe.

Słowa kluczowe: aktywność przeciwbakteryjna, aktywność przeciwgrzybicza, olejek eteryczny, Aloe, Chelidonium 


\section{Introduction}

Plants with medicinal properties have a recognized place in the history of medicine, pharmacy and cosmetics, but their values for antiseptic, analgesic, anti-inflammatory and soothing effects are also acknowledged today [1-3]. Plants characteristic for specific geographical and climatic regions or occurring endemically are often treated as potential sources of new biologically active substances [4,5]. Issues related to the analysis of antimicrobial activity of active substances contained in plant raw materials are currently of interest to medicine as well as medical and life sciences, in addition to the broadly defined food and cosmetic industry. Much attention is also paid to the role of spice plants, both native, those traditionally used in Central European countries, and those imported from Mediterranean and tropical climates. Spice plants not only affect the taste or pro-health properties of dishes but are also important in prolonging the shelf life of food due to their antibacterial and antifungal effects [6].

The aim of this study was to analyze the importance of selected medicinal and spice plants in terms of their inhibitory effect on the growth of microorganisms, including those pathogenic to humans.

\section{Plants with high antimicrobial potential}

The genus Aloe comprises over 400 species including candelabra aloe (Aloe arborescens Mill.), aloe vera (Aloe barbadensis Mill., commonly referred to as Aloe vera L.) and Aloe ferox Mill. [7-10]. The pulp or juice obtained from fresh leaves is used to prepare products of therapeutic value, whereby the content of active substances in the finished product depends on the species of aloe vera used, the age of the plants, the climate in which they grew and the conditions in which they were cultivated. The type of substance used to perform the extraction and the conditions under which the process takes place are also important [7]. The use of water as an eluent and elution at the boiling point of water, allows to obtain a product with a high content of active substances with a stimulatory effect on the cellular response of the immune system [9]. A number of different biologically active substances have been found in the gel contained in aloe leaves, including: anthraquinones (aloin, emodin), polysaccharides (mannose, arabinose, glucose, galactose, galacturonic acid, xylose, fucose and rhamnose) and enzymes (amylase, catalase, peroxidase), minerals (zinc, copper, selenium, calcium), vitamins (A, C, E, B12), fatty acids (lupeol, campesterol), hormones (auxins and gibberellins), readily available amino acids, salicylic acid, lignin and saponin [7,8,10,11]. The active substances contained in Aloe vera show antioxidant, antibacterial and prebiotic, anticancer, hypoglycaemic, hypolipidaemic and anti-inflammatory effects [10,11], in addition to protective effects against gastrointestinal diseases and cardioprotective effects [11]. Lectins (alloctin-A and alloctin-B) isolated from $A$. arborescens exhibit immunochemical and hemagglutination properties and stimulate mitosis and an increase in the absolute number of lymphocytes, as confirmed by in vitro studies [8,12]. Beta-sitosterol, salicylic acid, campesterol, bradykinase contained in aloe juice show anti-inflammatory effects, whereas antimicrobial (antibacterial, antifungal) effects are exerted by, among others, phenols, cinnamic acid, chrysophanic acid, lupeol and sulfur compounds [8,9]. Compounds from the group of non-mucosal polysaccharides (acemannan, $\beta$-mannan, glucomannan, arabinogalactan) show antiviral activity [7].

An inhibitory effect of aloe on the growth of Pseudomonas aeruginosa, Enterococcus faecalis, Helicobacter pylori, Escherichia coli and the fungi Candida albicans and the formation of biofilm by methicillin resistant Staphylococcus aureus (MRSA) has been demonstrated [11,13]. The antimicrobial activity of A. vera against E. faecalis is attributed to anthraquinones [13]. Studies conducted by Tariq et al. have shown that some tested fractions of $A$. vera, differing in total phenolic content (TPC) and total flavonoid content (TFC), significantly inhibit the growth of $P$. aeruginosa (MIC 0.70, 0.71, 7.72, $8.68 \mu \mathrm{g} / \mathrm{ml}$ ) [10].

According to Cieślik, fresh Aloe vera juice containing anthraquinones and salicylic acid has a bacteriostatic effect against the bacteria Salmonella typhi, Salmonella paratyphi and Shigella. The indirect antimicrobial effect is due to polysaccharides, which stimulate the growth of probiotic microbiota which inhibit the growth of bacteria of the genera Bacteroides, Clostridium and Fusobacterium [8].

Chelidonium majus L. (greater celandine) contains biologically active substances with a very broad spectrum of activity: from antiviral, through antibacterial, antifungal, to antiprotozoal and antiparasitic [14,15]. Additionally, anti-inflammatory, antispasmodic, spasmolytic and cholekinetic activities have been described [14]. C. majus alkaloids exhibit different biological activities due to differences in molecular structure, and their bioactive potential is very high and continuously being studied $[14,16]$. Studies conducted by Zielińska et al. showed the presence of seven major alkaloids from three classes (phenanthridine: chelidonine, chelerythrine, sanguinarine; protoberberine: berberine, coptisine; protopine: allocryptopine, protopine). This study further showed that the alkaloid content was higher in the roots than in the aboveground parts. Coptisine was predominant in the aboveground parts, while sanguinarine was predominant in the roots [14]. 
The study conducted by Kędzia et al. shows that the antibiotic activity of ethanolic extracts from the herb $C$. majus is more than 2.5 times higher than that of aqueous extracts. Ethanolic extracts also contain more alkaloids and flavonoids compared to aqueous extracts. As concluded by the authors of the study, the ethanol extract of the herb C. majus, due to its broad bactericidal spectrum against Gram-positive bacteria (S. aureus MRSA, Streptococcus pneumoniae, Streptococcus pyogenes, Streptococcus agalactiae, E. faecalis, Streptococcus faecium, Moraxella catarrhalis) and Gram-negative (E. coli, Klebsiella pneumoniae, P. aeruginosa) may be of practical importance in the treatment of wounds and burns infected with microorganisms [15].

Other findings indicate that chelerythrine is highly effective against $P$. aeruginosa (MIC $1.9 \mathrm{mg} / \mathrm{L}$ ), sanguinarine against $S$. aureus (MIC at $1.9 \mathrm{mg} / \mathrm{L}$ ) and chelerythrine and chelidonine against $C$. albicans (MIC at 31.25 and $62.5 \mathrm{mg} / \mathrm{L}$ respectively). It was also confirmed that the alkaloid mixtures sanguinarine-chelerythrine and sanguinarine-chelerythrine-berberine were more effective against $S$. aureus than against $P$. aeruginosa and C. albicans [14].

\section{Antimicrobial action of plant oils}

Essential oils extracted from various parts of herbs and citrus plants have also been shown to have antimicrobial effects (leaves, flowers, fruits, seeds, bark). A large group, of considerable importance in various fields of industry, are essential oils from citrus fruits: lemons (Citrus limon (L.) Osbeck), grapefruit (Citrus $x$ paradisi Macfad), sweet oranges (Citrus sinensis L.), bitter oranges (Citrus aurantium L.) and mandarins (Citrus reticulata Blanco). Citrus essential oils are used, among other things, as food additives and as natural preservatives [17]. This group of compounds is continuously being studied for their potential use in this area of industry [18]. It is assumed that compounds belonging to groups such as terpenes, sesquiterpenes, flavonoids, carotenes and coumarins are responsible for the strong antioxidant and antimicrobial activity of these oils $[17,18]$.

The chemical composition of citrus fruit oils varies and depends on many factors, including the species of plant, its growing climate and stage of maturity, the type of raw material used (fruit, leaves, flowers) and the extraction methods used. The main constituents of essential oils of sweet and bitter orange, mandarin and grapefruit are monoterpenes, mainly $d$-limonene (65.3-95.9\%). Bitter orange leaf oil contains linalyl acetate and linalool, while the flower oil is rich in linalool as well as $d$-limonene and linalyl acetate [17].

From the common lemon (Citrus limon (L) Burm. f.), the essential oil (Oleum citri) is extracted from the outer pericarp by cold pressing. Limonene (50-90\%) as well as citral, $\alpha$-terpineol, $\alpha$-pinene, $\beta$-pinene, citronellal, linalyl acetate, geranyl acetate, $p$-cymene, g-pinene, $\beta$-myrcene, coumarins, bioflavonoids and pectin are the main compounds responsible for its biological activity. Kędzia et al. conducted a study on the sensitivity to lemon oil of anaerobic bacteria isolated from patients with periodontal disease, oral mucositis and periodontal abscesses. The study showed that Gram-positive (G+) anaerobic bacteria were more sensitive to lemon oil compared to Gram-negative (G-) anaerobic bacteria. Low concentrations of the oil in the range $\leq 2.5-10.0 \mathrm{mg} / \mathrm{ml}$ inhibited the growth by $32 \%$ for Gram-negative bacteria and $47 \%$ for Gram-positive strains of anaerobic bacteria. Lemon oil showed the highest activity against Gram-negative bacteria such as Porphyromonas asaccharolytica (MIC $\leq 2.5$ $\mathrm{mg} / \mathrm{ml}$ ) and Prevotella levii (MIC $\leq 2.5-7.5 \mathrm{mg} / \mathrm{ml}$ ) as well as the Gram-positive anaerobic bacteria Finegoldia magna and Micromonas micros ( $\mathrm{MIC} \leq 2.5-10.0 \mathrm{mg} / \mathrm{ml}$ ). The oil showed the lowest activity against Gram-negative bacteria such as Fusobacterium necrogenes and Bacteroides fragilis (MIC $>20.0 \mathrm{mg} / \mathrm{ml}$ ). Gram-positive bacteria belonging to the genus Actinomyces (A. izraelii, A. odontolyticus, A. viscosus) and Bifidobacterium proved to be slightly more sensitive to the tested oil (MIC in the range of $10.0-15.0 \mathrm{mg} / \mathrm{ml}$ ) than bacteria of the genus Propionibacterium (P. acnes, P. granulosum; MIC $\geq 20.0 \mathrm{mg} / \mathrm{ml}$ ) [19]. In other studies, it has been shown that $S$. aureus is highly sensitive to lemon oil - for $77 \%$ of the tested strains, the MIC was in the range of 7.5-10 mg/ml. Lower activity of the oil was found against Staphylococcus epidermidis and E. faecalis, and much lower activity against Gram-negative bacteria, where only single strains among Acinetobacter baumannii and K. pneumoniae were sensitive to $C$. limon essential oil [20]. Ben Hsoun's study suggests that the antimicrobial activity of $C$. limon essential oil against bacteria is variable. The largest zone of growth inhibition was found against Gram-positive bacteria: Listeria monocytogenes $(26 \mathrm{~mm})$, Bacillus cereus $(24 \mathrm{~mm})$ and S. aureus $(22 \mathrm{~mm})$. For Gram-negative bacteria, the highest zone of growth inhibition was found for Salmonella enteritidis $(18 \mathrm{~mm})$. The positive control was gentamicin, for which the zone of growth inhibition for bacteria ranged from 12 to $25 \mathrm{~mm}$ [18]. Other sources also confirm the antimicrobial activity of lemon oil against B. cereus, L. monocytogenes, E. coli, K. pneumoniae, $S$. aureus, among others, and antifungal activity against Aspergillus niger, Aspergillus flavus, C. albicans [17].

Grapefruit essential oil (C. paradisi) shows antibacterial (B. cereus, E. faecalis, E. coli, K. pneumoniae, Salmonella thyphimurium, S. aureus) and antifungal activity (A. niger, C. albicans). In certain concentrations it also damages the eggs and larvae of Anastrepha fraterculus, Ceratitis capitata i Aedes aegypti and the larvae of Anopheles stephensi. 
Bergamot oil (Citrus Bergamia Risso \& Poit) has shown activity against Mycoplasma hominis, Mycoplasma fermentans and Mycoplasma pneumoniae. It is interesting to note that lime oil (Citrus aurantifolia), in addition to its antibacterial (E. coli, L. monocytogenes, B. subtilis, S. epidermidis, S. aureus, P. aeruginosa, K. pneumoniae, S. typhi) and antifungal (A. niger, A. parasiticus, $C$. albicans, $C$. parapsilosis) effects, exhibits phytotoxicity against the plants Avena fatua L., Echinochloa crus-galli (L.) Beauv, Allium cepa L. and Phalaris minor Retz [17].

Caraway oil (Oleum carvi), which is obtained by steam distillation from the crushed fruit of the caraway plant (Carum carvi L.), a popular spice plant, also has an antimicrobial effect. The main components of caraway oil include carvone, limonene, cis-carveol and $\alpha$-pinene. According to a study by Kędzia et al., different species of anaerobic bacteria (Gram-positive and Gram-negative) isolated from materials collected from patients with oral infections differ in their sensitivity to caraway oil. Gram-positive anaerobic cocci have been shown to have higher sensitivity to caraway oil than Gram-positive bacilli. The highest sensitivity to caraway oil was shown by Gram-negative bacilli Tannerella forsythia and Bacteroides uniformis. Caraway oil inhibited the growth of these bacteria at concentrations $<0.06-0.12 \mathrm{mg} / \mathrm{ml}$ and $0.12-0.25 \mathrm{mg} / \mathrm{ml}$, respectively. The least sensitive to caraway oil were Prevotella intermedia, Prevotella buccalis, Prevotella bivia, Porphyromonas asaccharolytica, Porphyromonas gingivalis, B. fragilis, Bacteroides ureolyticus and Parabacteroides distasonis (MIC $\geq 2.0 \mathrm{mg} / \mathrm{ml}$ ). The oil showed the highest activity against Gram-positive bacilli of Actinomyces genus (MIC $\leq 0.06-0.5 \mathrm{mg} / \mathrm{ml}$ ) and Peptostreptococcus anaerobius (MIC for $83 \%$ of strains $\leq 0.06-0.5 \mathrm{mg} / \mathrm{ml}$ ). The bacteria $B$. breve did not show sensitivity to caraway oil (MIC $>2.0 \mathrm{mg} / \mathrm{ml}$ ) [21].

The antimicrobial effects of oil and essential oil from cannabis sativa (Cannabis sativa L.) seeds have also been proven. This oil contains $\alpha$ - and $\beta$ - linolenic acids, fatty acids - palmitic, stearic - as well as cannabidiol, $\Delta$ 9-tetrahydrocannabinol, myrcene, $\beta$-caryophyllene, $\beta$-sitosterol and $\alpha$ - and g-tocopherol. The essential oil of cannabis sativa seeds contains $\alpha$-pinene, myrcene, trans- $\beta$-ocimene, $\alpha$-terpineolene, $\alpha$-humulene and transcaryophyllene. Both the oil and essential oil of $C$. sativa show activity against bacteria, fungi, viruses, protozoa, parasites and insects [22]. Gram-positive bacterial strains isolated from patients with oral infections were more sensitive to cannabis sativa essential oil than Gram-negative anaerobic bacilli strains. Gram-negative bacterial strains of the genus Prevotella and Porphyromonas (MIC 3.1-6.2 mg/ml) and T. forsythia and P. distasonis (MIC $6.2 \mathrm{mg} / \mathrm{ml}$ ) showed significant sensitivity to the effects of cannabis sativa essential oil. The lowest sensitivity was found in strains of the genus Bacteroides and Fusobacterium (MIC $\geq 12.5 \mathrm{mg} / \mathrm{ml}$ ). Gram-positive strains of Finegoldia magna, P. anaerobius and Parvimonas micra (MIC 0.8-12.5 mg/ml), Gram-positive bacilli $B$. breve, $P$. acnes and P. granulosum (MIC 1.6-3.1 mg/ml) showed high sensitivity to cannabis sativa oil [22].

Clove oil (Oleum Caryophylli) as well as clove extract (Syzygium aromaticum (L.) Merr. \& Perry) are used as natural antiseptics in products. The main active ingredient in both the clove oil and the extract is eugenol, which can inhibit the production of amylase and protease by $B$. cereus and has the ability to destroy bacterial cell walls leading to lysis. Studies have shown that the aqueous extract of clove shows antibacterial activity against $S$. aureus (MIC $2 \mathrm{mg} / \mathrm{ml}$ ) and E. coli (MIC $2.5 \mathrm{mg} / \mathrm{ml}$ ) as well as against Clostridium botulinum, the ethanol extract is active against L. monocytogenes (MIC $0.24 \mathrm{mg} / \mathrm{ml}$ ) while clove oil is not only bactericidal (against $B$. cereus, $S$. typhimurium, $E$ coli) but also fungicidal against $C$. albicans [6]. Oils from other spice plants: common thyme (Thymus vulgaris L.) [23], cumin (Cuminum cyminum L.), rosemary (Rosmarinus officinalis L.), great basil (Ocimum basilicum L.) [6], English lavender (Lavandula angustifolia L.) [24] also show antimicrobial activity.

\section{Antifungal activity of substances derived from plants}

A yeasticidal effect against Candida has been demonstrated by eucalyptus oil (Eucalyptus globulus oil), which contains compounds such as 1,8-cineole, $\alpha$-pinene, $\beta$-pinene, limonene, g-terpinene [25]. It has been shown experimentally that at different concentrations it inhibited the growth of: Candida guilliermondii and Candida parapsilosis (1.25-2.5 mg/ml), Candida lusitaniae and Candida utilis (2.5 mg/ml), Candida glabrata (2.5-5.0 mg/ $\mathrm{ml}$ ), C. albicans $(1.25-2.5 \mathrm{mg} / \mathrm{ml}$ for $55 \%$ of the tested strains and $5.0 \mathrm{mg} / \mathrm{ml}$ for the other $45 \%$ of strains). The weakest inhibitory effect of the oil was observed against Candida tropicalis. The growth of $80 \%$ of the strains of this species was inhibited at an oil concentration of $7.5 \mathrm{mg} / \mathrm{ml}$ [26]. Other studies have shown activity of eucalyptus oil against $C$. albicans ATCC 10231. For $C$. albicans from clinical isolates, the minimum inhibitory concentration (MIC) was $0.36 \mathrm{mg} / \mathrm{ml}$ and the minimum bactericidal concentration (MBC) was $0.72 \mathrm{mg} / \mathrm{ml}$ [25].

Cinnamon oil (Oleum Cinnamomi) extracted from the bark of the Ceylon cinnamon tree (Cinnamomum verum J. Presl) contains cinnamaldehyde, trans-cinnamic acid, cinnamic alcohol, benzaldehyde, eugenol, limonene, cuminol, $\alpha$-pinene, $\alpha$-terpineol. Studies have shown that among yeast-like fungi isolated from patients with oral candidiasis, cinnamon oil inhibited the growth of $83 \%$ of $C$. glabrata strains, $67 \%$ of $C$. guilliermondii strains and $67 \%$ of $C$. utilis strains and $17 \%$ of $C$. albicns strains (MIC $\leq 0.06-0.12 \mathrm{mg} / \mathrm{ml}$ ), whereas oil concentrations of 0.25 
$\mathrm{mg} / \mathrm{ml}$ inhibited the growth of $83 \%$ of C. albicans strains. Against Candida kefyr and Candida krusei cinnamon oil was active in a concentration range of $0.25-0.5 \mathrm{mg} / \mathrm{ml}$ [27]. Cinnamon oil not only exhibits antifungal but also antibacterial activity and prevents the formation of biofilm by $S$. aureus MRSA. This effect has been shown to be due to the effects of cinnamaldehyde, the main component of this essential oil, on the inhibition of cell wall synthesis, cell membrane function and enzyme activity [6]. The antifungal effect of the essential oil of wild oregano (Origanum vulgare L.) has also been demonstrated. Its properties are mainly due to two active compounds, carvacrol and thymol, which are likely to alter the permeability of cell membranes to low molecular substances. Among other things, the oil is active against $C$. albicans, $C$. krusei and $C$. tropicalis. Growth inhibition of $C$. glabrata was observed with mean MIC values of $340.2 \mu \mathrm{g} / \mathrm{ml}$. Essential oil of common thyme $(T$. vulgaris) exhibits antifungal activity against $C$. albicans but also antibacterial activity against $E$. coli, $S$. aureus, $S$. epidermidis, $P$. aeruginosa and B. subtilis. The MIC values found for fungi were within the range of $80-97 \mu \mathrm{g} / \mathrm{ml}$, while for bacteria within the range of $75-1100 \mu \mathrm{g} / \mathrm{ml}[6]$.

Candida albicans, as a commensal fungus, may be present in a population colonizing the gastrointestinal tract, skin and female reproductive tract in at least $70 \%$ of healthy adults. Colonization usually occurs during infancy, and studies have shown that these strains continue to occur for many years thereafter. Mild commensal colonization can change its character to pathogenic in the event of developing immunological disorders or mucosal damage. The susceptibility of patients to Candida spp. infections has increased with the availability of modern treatments, including antibiotic therapy, cancer chemotherapy and solid organ transplantation. Candida species are now one of the causes of invasive bloodstream infections. In this context, it is important to study the mechanisms by which Candida spp. colonize diverse niches in their hosts, persist in the microbiota alongside numerous bacterial populations and live as commensals. The key issue is related to factors controlling the transition from commensalism to pathogenicity and, consequently, the development of deep and generalized mycoses [28]. Hołderna-Kędzia et al. studied the effects of plant extracts, among others, on a model strain $C$. albicans PCM 1409 PZH. The strongest inhibitory effect on the growth of the tested strain $(\leq 100 \mu \mathrm{g} / \mathrm{ml}) \mathrm{was}$ shown by the ethanolic extracts from the root of elecampane (Inula helenium L.), leaves of rosemary (Rosmarinus officinalis L.), leaves of common sage (Salvia officinalis L.) and the herb Lepidium sativum L., roots of Lithospermum canescens (Michx.) Lehm. The strongest inhibitory effect $(\leq 100 \mu \mathrm{g} / \mathrm{ml})$ was found for a complex of sulfur compounds from the bulbs of Allium sativum L. (common garlic), alkaloids from Chelidonium majus L. (greater celandine) and glycosides from the roots of Rubia tinctorum L. (rose madder). The effect of plant substance complexes on the growth of clinical strains of $C$. albicans has also been analyzed - the strongest inhibitory effect $(\leq 100 \mu \mathrm{g} / \mathrm{ml}$ ) was recorded for a complex of sulfur compounds from the bulbs of Allium sativum L. and a complex of furanocoumarin compounds isolated from the fruits of Heracleum sosnowskyi Manden (Sosnowsky's hogweed) and Archangelica officinalis Hoffm. (angelica archangelica). According to the authors of the study, in the case of Heracleum sosnowskyi Manden and Archangelica officinalis Hoffm, the practical use of their properties is hampered by their potential to cause allergic reactions [29].

Modern research into the medicinal effects of plant substances uses the latest technologies and analytical techniques, and the traditional use of medicinal plants is supported by multidirectional scientific research. New substances present in raw plants are constantly being discovered, which may be of importance in medicine because of their great potential to destroy microorganisms or because of their antioxidant and anticancer properties [30].

\section{Conclusions}

Plants are a rich source of many substances with a broad spectrum of activity, including antimicrobial activity. This knowledge was often used in folk medicine, but it was not until the development of modern research methods that it has become possible to understand the mechanisms underlying the therapeutic properties of many substances of plant origin and how to use them properly.

\section{References:}

1. Kędzia A, Kusiak A, Kochańska B, Lassmann Ł, Wojtaszek-Słomińska A, Kędzia AW. [The activity of Aromatol against anaerobic bacteria]. Post Fitoter. 2015; (16)4: 210-215 (in Polish).

2. Ziółkowska-Klinkosz M, Kędzia A. [Activity of Listerine against aerobic bacteria]. Post Fitoter. 2014; 15(1): 10-14 (in Polish).

3. Kędzia A, Kusiak A, Kochańska B, Lassmann Ł, Wojtaszek-Słomińska A, Gębska A. [Activity of cedar oil (Oleum Cedri) on aerobic bacteria]. Post Fitoter. 2015; 16(3): 135-138 (in Polish). 
4. Ginovyan M, Petrosyan M, Trchounian A. Antimicrobial activity of some plant materials used in Armenian traditional medicine. BMC Complement Altern Med. 2017; 17: 50. https://doi.org/10.1186/s12906-017-1573-y

5. Carrol DH, Chassagne F, Dettweiler M, Quave CL. Antibacterial activity of plant species used for oral health against Porphyromonas gingivalis. PLoS ONE. 2020; 15(10): e0239316. https://doi.org/10.1371/journal.pone.0239316

6. Liu Q, Meng X, Li Y, Zhao CN, Tang GY, Li HB. Antibacterial and antifungal activities of spices. Int J Mol Sci. 2017; 18(6): 1283. https://doi.org/10.3390/ijms18061283

7. Anuszewska E, Drozd J, Drozd E, Gruber B. [Immunomodulatory activity of two polysaccharide fractions isolated from Biostymina ${ }^{\circledR}$ (Aloe arborescens folii recentis extractum fluidum). Post Fitoter. 2015; (16)2: 83-88 (in Polish).

8. Cieślik E, Turcza K. [The health benefits of Aloe vera (L.) Webb. (Aloe barbadensis Mill.)]. Post Fitoter. 2015; (16)2: 117-124 (in Polish).

9. Drozd J, Januszewska EL. [Immunostimulatory activity of water extract from leaves of Aloe arborescens Mill.]. Post Fitoter. 2014; (15)1: 23-27 (in Polish).

10. Tariq H, Zia M, Ihsan-ul-Haq, Muhammad SA, Khan SA, Fatima N, et al. Antioxidant, antimicrobial, cytotoxic, and protein kinase inhibition potential in Aloe vera L. Biomed Res Int. 2019; $2019: 6478187$. https://doi.org/10.1155/2019/6478187

11. Sánchez M, González-Burgos E, Iglesias I, Gómez-Serranillos MP. Pharmacological update properties of Aloe vera and its major active constituents. Molecules. 2020; 25(6): 1324. https://doi.org/10.3390/molecules25061324

12. Park SJ, Ahmad F, Philp A, Baar K, Williams T, Luo H, et al. Resveratrol ameliorates aging-related metabolic phenotypes by inhibiting cAMP phosphodiesterases. Cell. 2012; 148: 421-33. https://doi.org/10.1016/j.cell.2012.01.017

13. Varshini R, Subha A, Prabhakar V, Mathini P, Narayanan S, Minu K. Antimicrobial efficacy of Aloe vera, lemon, Ricinus communis, and calcium hydroxide as intracanal medicament against Enterococcus faecalis: a confocal microscopic study. J Pharm Bioallied Sci. 2019; 11(Suppl 2): S256-S259. https://doi.org/10.4103/JPBS.JPBS_5_19

14. Zielińska S, Wójciak-Kosior M, Dziągwa-Becker M, Gleńsk M, Sowa I, Fijałkowski K, et al. The activity of isoquinoline alkaloids and extracts from Chelidonium majus against pathogenic bacteria and Candida sp. Toxins (Basel). 2019; 11(7): 406. https://doi.org/10.3390/toxins11070406

15. Kędzia B, Hołderna-Kędzia E, Seidler-Łożykowska K, Buchwald W, Krajewska-Pattan A, Gryszczyńska A. et al. [Antibiotic activity and chemical composition of extracts obtained from herb and seedlings of Chelidonium majus L.]. Post Fitoter. 2015; (16)2: 67-71 (in Polish).

16. Zielińska S, Czerwińska ME, Dziągwa-Becker M, Dryś A, Kucharski M, Jezierska-Domaradzka A, et al. Modulatory effect of Chelidonium majus extract and its alkaloids on LPS-stimulated cytokine secretion in human neutrophils. Molecules. 2020; 25(4): 842. https://doi.org/10.3390/molecules25040842

17. Dosoky NS, Setzer WN. Biological activities and safety of Citrus spp. essential oils. Int J Mol Sci. 2018; 19(7): 1966. https://doi.org/10.3390/ijms19071966

18. Ben Hsouna A, Ben Halima N, Smaoui S, Hamdi N. Citrus lemon essential oil: chemical composition, antioxidant and antimicrobial activities with its preservative effect againstListeria monocytogenes inoculated in minced beef meat. Lipids Health Dis. 2017; 16: 146. https://doi.org/10.1186/s12944-017-0487-5

19. Kędzia A, Ziółkowska-Klinkosz M, Włodarkiewicz A, Kusiak A, Kędzia AW, Kochańska B. [Sensitivity of anaerobic bacteria to lemon oil (Oleum Citri)]. Post Fitoter. 2013; (14)2: 71-75 (in Polish).

20. Kędzia A, Kusiak A, Ziółkowska-Klinkosz M, Gębska A, Wojtaszek-Słomińska A, Wierzbowska M. [The activity of citri oil (Ol. Citri) on aerobic bacteria]. Post Fitoter. 2016; 17(1): 8-11 (in Polish).

21. Kędzia A, Ziółkowska-Klinkosz M, Wojtaszek-Słomińska A, Kędzia AW, Kusiak A, Włodarkiewicz A. [Activity in vitro of Caraway oil (Oleum carvi) against anaerobic bacteria]. Post Fitoter. 2013; 14(1): 3-7 (in Polish).

22. Kędzia A, Ziółkowska-Klinkosz M, Kochańska B, Kędzia AW, Gębska A. [Evaluation of activity essential oil from Cannabis sativa L. against anaerobic bacteria]. Post Fitoter. 2014; 15(3): 136-140 (in Polish).

23. Kędzia A, Ziółkowska-Klinkosz M, Lassmann Ł, Włodarkiewicz A, Kusiak A, Kochańska B. [The susceptibility of microaerophilic bacteria to thyme oil (Oleum Thymi) isolated from infection of oral cavity]. Post Fitoter. 2013; 14(3): 159-162 (in Polish).

24. Daszyńska M, Swarcewicz M, Markowska-Szczupak A. [Comparison of chemical composition and antimicrobial activity of lavender varieties from Poland]. Post Fitoter. 2013; 14(2): 90-96 (in Polish).

25. Damjanović-Vratnica B, Dakot T, Šuković D, Damjanović J. Antimicrobial effect of essential oil isolated from Eucalyptus globulus Labill. from Montenegro. Czech J. Food Sci. 2011; 29(3): $277-284$. https://doi.org/10.17221/114/2009-CJFS 
26. Kędzia A, Ziółkowska-Klinkosz M, Kochańska B, Kusiak A, Wojtaszek-Słomińska A, Kędzia AW. [Antifungal activity of eucalyptus oil (Oleum eucalypti)]. Post Fitoter. 2014; 15(2): 63-66 (in Polish).

27. Kędzia A, Ziółkowska-Klinkosz M, Kusiak A, Kochańska B, Kędzia AW, Wojtaszek-Słomińska A. [The activity in vitro of cinnamon oil (Oleum Cinnamomi) against yeastlike fungi]. Post Fitoter. 2015; (16)1: 16-20 (in Polish).

28. Noble SM, Gianetti BA, Witchley JN. Candida albicans cell type switches and functional plasticity in the mammalian host. Nat Rev Microbiol. 2017; 15(2): 96-108. https://doi.org/10.1038/nrmicro.2016.157

29. Hołderna-Kędzia E, Wolski T, Kędzia B. [The activity of extracts and plant complexes on pathogenic fungi on the base of own studies]. Post Fitoter. 2014; 15(4): 200-204 (in Polish).

30. Ocampo Y, Caro D, Rivera D, Piermattey J, Gitan R, Franco LA. Transcriptome changes in colorectal cancer cells upon treatment with Avicequinone B. Adv Pharm Bull. 2020; 10(4): 638-647. https://doi.org/10.34172/ apb.2020.077 